\title{
Uji Fitokimia Senyawa Metabolit Sekunder Dalam Ekstrak Metanol Bunga Turi Merah (Sesbania grandiflora L. Pers)
}

\author{
Anjar Purba Asmara \\ Program Studi Kimia, Fakultas Sains dan Teknologi, Universitas Islam Negeri Ar-Raniry \\ Jl. Syeikh Abdul Rauf Kopelma Darussalam Banda Aceh \\ Email: anjarpa@ar-raniry.ac.id
}

\begin{abstract}
A beginning investigation about the presence of secondary metabolite compounds in the methanol extract of red grandiflora flower (Sesbania grandiflora L. Pers) has been conducted. The flower which traditionally used as antihyperglycemic therapy has been extracted through methanolic-maceration. The crude extract was phytochemically analyzed by qualitative approach with specific reagent for the each type of the compound. The analysis of functional group prediction is also performed by using FTIR spectrometer. Phytochemical test showed that it contains alkaloid, tannin, polyphenol, flavonoid, quinone, and triterpenoid. The IR spectrum showed that the typical functional group of the secondary metabolite consist of hydroxide $(-\mathrm{OH})$, olefin $(C=C)$, and aromatic which as constituents of phenolic group.
\end{abstract}

Keywords: extraction; phytochemical; red grandiflora flower; secondary metabolite

\section{PENDAHULUAN}

Indonesia merupakan negara yang kaya akan keanekaragaman hayati. Hal ini terjadi karena didukung oleh iklim tropis dan kondisi geografis yang mendukung tumbuhnya bermacammacam tanaman. Salah satu tanaman yang tumbuh subur di Indonesia adalah turi (Sesbania grandiflora L. Pers). Tanaman ini memiliki nama bermacam-macam di belahan dunia, yaitu agusta, bagphal, agati (Bengali), caturay, katurai (Chamorro), pwa valet, pwa valye (Creole Patosi), flamingo bill, grandiflora, Australian corkwood tree, August flower, sesban, agati sesbania, west Indian pea, white dragon tree, vegetable-hummingbird, tiger tongue, swamp pea (English), gauai-gauai, katurai, katuday (Filipino), pois vallier, colbri vegetal, fleur papillon, fagotier, (French), basna, chogache, basma, agasti, hatiya, daincha (Hindi), turibaum (German), tuwi, turi, toroy (Indonesia), sesbania (Italian), ângkiëdèi (Khmer), kh'ê khaw, sino- de gallo, baculo, zapaton blanco, gallito, pico de flamenco (Spanish) (Jiraungkoorskul et al, 2013).

Turi merupakan tanaman asli daerah Asia Tenggara dan juga banyak dijumpai di Asia Selatan dan Afrika (Reji et al, 2013 dan Munde-Wagh et al, 2012). Tinggi pohonnya bisa mencapai $15 \mathrm{~m}$ dengan tangkai daun sepanjang $30 \mathrm{~cm}$ dan jumlahnya sebanyak 20-50 buah pertangkai. Bunganya ada yang berwarna putih kekuningan dan ada yang merah dengan panjang kelopak 15,22 mm (Reji et al, 2013). 
Tanaman turi memiliki banyak manfaat. Tanaman digunakan untuk mencegah erosi, getahnya untuk zat pewarna tekstil, kayunya digunakan untuk bahan bangunan, daun dan batangnya yang muda juga dimanfaatkan untuk pakan ternak. Daun muda, polong biji, dan bunganya juga enak dikonsumsi manusia sebagai lalapan maupun sayur. Bagian-bagian tanaman ini seperti batang, kulit batang, akar, daun, dan juga bunganya digunakan untuk pengobatan tradisional mengatasi flu, demam, sakit perut, diare, dan kulit kusam (Powthong et al, 2012 dan Hasan et al, 2012). Daunnya memiliki sifat antixiolitik dan antikonvulsan sedangkan bunganya mengandung zat antimikrobial (Avalaskar et al, 2011).

Bioaktivitas bagian tanaman turi ini disebabkan oleh bagian-bagian tumbuhan ini mengandung senyawa-senyawa metabolit sekunder. Ekstrak metanol daun turi dilaporkan mengandung alkaloid, glikosida, steroid, terpenoid dan tanin yang dianalisis dengan GC - MS. Penelitian ini menunjukkan ada 18 senyawa utama seperti: 3,4,5-Trimetoksifenol (2,5\%), asam erusat (2,8 \%), 2-Furankarboksaldehida (2,8 \%), vitamin E asetat (3,13\%), 4-metiloksazol (5\%), asam palmatat (11,8 \%), 9-heksadesenol (9,0 \%), dioktil ester (10,1\%) (Hussain et al, 2014). Penelitian lainnya menganalisis kandungan senyawa golongan isoflavanoid dalam akar tanaman turi yang berupa isovestisol, medikarpin, sativan, dan asam betulinat (Hasan et al, 2012).

Bagian tumbuhan turi lainnya yang memiliki potensi bioaktivitas yang tinggi adalah bunganya. Jenis bunganya ada dua yaitu bunga turi merah dan putih namun menurut pengamatan peneliti populasi bunga turi merah lebih sedikit dibandingkan bunga turi putih. Keduanya memiliki potensi mikrobial yang tinggi karena mengandung senyawa metabolit sekunder seperti bagian tumbuhan turi yang lain. Bunga turi merah dimanfaatkan masyarakat pedesaan untuk pengobatan kencing manis atau diabetes.

Penelitian yang khusus menganalisis senyawa metabolit sekunder di dalam bunga turi merah ini belum banyak. Hal ini yang melatarbelakangi perlu dilakukan penelitian awal untuk uji fitokimia dan memprediksi gologan senyawa metabolit sekunder yang terkandung di dalamnya sebelum dilakukan isolasi dan karakterisasi senyawanya. Pelarut yang digunakan dalam penelitian ini adalah metanol berdasarkan laporan Padmalochana dan Rajan (2014) bahwa pelarut yang lebih polar dan lebih mudah menguap berhasil mengekstrak senyawa bioaktif yang lebih banyak daripada pelarut pembandingnya.

\section{METODE PENELITIAN}

\section{Bahan}

Metanol (Merck, pa), kloroform (Merck), amoniak 10\%, asam sulfat pekat (Merck), $\mathrm{NaCl}$ $10 \%$, reagen Follin-Ciocalteau (50\% v/v), larutan natrium karbonat $(7,5 \% \mathrm{~b} / \mathrm{v})$, serbuk $\mathrm{Mg}, \mathrm{HCl}$ pekat, $\mathrm{NaOH} 1 \mathrm{M}, \mathrm{KOH} 0,5 \mathrm{M}$, hidrogen peroksida $5 \%$, etanol 70\%, dan $\mathrm{KBr}$.

\section{Alat}


Peralatan gelas, rotary evaporator, kertas saring Whatmann no 1, dan spektrofotometer FTIR Perkin Elmer 100 (Perkin Elmer, Inc., USA).

\section{Prosedur}

\section{Preparasi}

Sampel berupa bunga turi merah (Sesbania grandiflora L. Pers.) yang segar dipetik dan dikumpulkan dari ladang tegalan di daerah Wonosari Gunungkidul. Foto sampel digunakan untuk identifikasi taksonominya menggunakan perangkat lunak berbasis Android, Kamus Taksonomi Tumbuhan, yang dirilis oleh tim peneliti FMIPA Universitas Pakuan Bogor (2014).

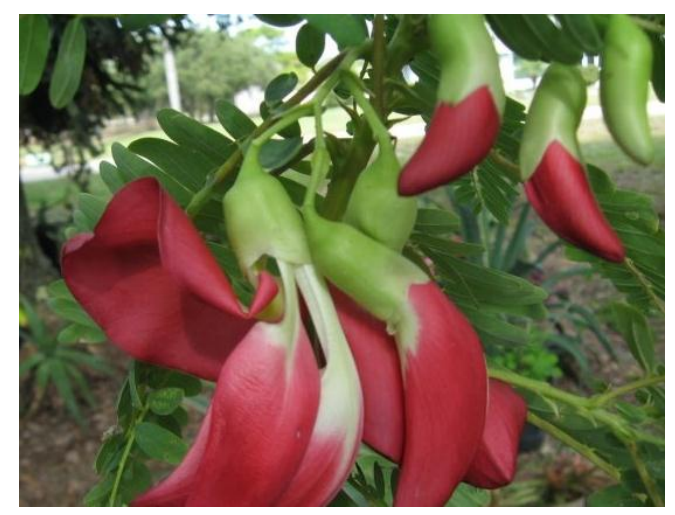

Gambar 1. Foto bunga turi merah (Sesbania grandiflora L. Pers.)

Sampel disimpan di tempat yang sejuk lalu dikeringkan dengan cara diangin-anginkan di udara terbuka yang terlindung dari sinar matahari selama 7 hari. Bunga yang sudah kering berwarna kecoklatan kemudian dirajang hingga halus lalu diblender hingga lembut.

\section{Ekstraksi}

Sebanyak 10 gram sampel berupa serbuk halus bunga turi merah (Sesbania grandiflora L. Pers.) dimaserasi dengan $50 \mathrm{~mL}$ metanol (pa) selama $7 \times 24$ jam, setiap 24 jam pelarut diganti dengan yang baru hingga filtrat tidak berwarna. Filtrat dipekatkan dengan rotary evaporator pada suhu $40{ }^{\circ} \mathrm{C}$ sehingga menghasilkan ekstrak kental metanol. Ekstrak kental metanol disuspensi dengan perbandingan metanol:air (2:1). Hasil partisi dari fraksi-fraksi tersebut dievaporasi pada suhu $30-40{ }^{\circ} \mathrm{C}$ sampai diperoleh ekstrak kental kemudian dilakukan uji fitokimia. 


\section{Uji Alkaloid}

Sebanyak $1 \times 10^{5} \mu \mathrm{g}$ ekstrak metanol dilarutkan dengan $5 \times 10^{3} \mu \mathrm{L}$ kloroform dan $5 \times 10^{3}$ $\mu \mathrm{L}$ amoniak dan hasilnya dibagi dalam dua tabung. Tabung pertama ditambahkan dengan 10 tetes asam sulfat $\left(\mathrm{H}_{2} \mathrm{SO}_{4}\right) 2 \mathrm{M}$. lapisan asam dipisahkan, dibagi dalam 2 tabung reaksi dan masing-masing tabung dilakukan pengujian dengan menggunakan pereaksi Wagner dan Dragendorff. Hasil positif (+) alkaloid untuk pereaksi Wagner ditunjukkan endapan coklat dan dengan pereaksi Dragendorff menunjukkan endapan jingga.

\section{Uji Saponin}

Ekstrak kental metanol yang diperoleh pada tahap ekstraksi ditimbang sebanyak $1 \times 10^{5} \mu \mathrm{g}$ dilarutkan dengan air panas sebanyak $15 \times 10^{3} \mu \mathrm{L}$ kemudian dipanaskan selama 5 menit. Selanjutnya disaring dan filtratnya diambil sebanyak $10 \times 10^{3} \mu \mathrm{L}$ dan dimasukkan ke dalam tabung reaksi. Larutan kemudian di kocok-kocok. Uji positif adanya saponin pada larutan ditandai dengan terbentuknya busa/buih.

\section{Uji Tanin}

Sebanyak $1 \times 10^{5} \mu \mathrm{g}$ ekstrak metanol dimasukkan ke dalam $10 \times 10^{3} \mu \mathrm{L}$ akuades panas kemudian didinginkan. Setelah itu ditambahkan 5 tetes $\mathrm{NaCl} 10 \%$ dan disaring. Filtrat dibagi 2 bagian A dan B. Filtrat A digunakan sebagai blangko, ke dalam filtrat B ditambahkan garam gelatin. Endapan putih menunjukkan hasil positif uji tanin.

\section{Uji Polifenol}

Sebanyak $1 \times 10^{5} \mu \mathrm{g}$ ekstrak metanol dimasukkan ke dalam $2 \times 10^{3} \mu \mathrm{L}$ etanol $96 \%$ dalam tabung reaksi. Campuran tersebut ditambahkan $5 \times 10^{3} \mu \mathrm{L}$ akuades dan $5 \times 10^{2} \mu \mathrm{L}$ reagen Follin-Ciocalteau ( $50 \%$ v/v), kemudian didiamkan selama 5 menit. Selanjutnya ditambahkan $1 \times$ $10^{3} \mu \mathrm{L}$ larutan natrium karbonat $(7,5 \% \mathrm{~b} / \mathrm{v})$, dihomogenasi dan diinkubasi pada suhu ruang selama 1 jam dalam kondisi tanpa cahaya (gelap). Hasil uji yang positif mengandung polifenol ditandai dengan perubahan warna menjadi biru gelap.

\section{Uji Flavonoid}

Ekstrak kental metanol sebanyak $1 \times 10^{5} \mu \mathrm{g}$ dilarutkan dalam $10 \times 10^{3} \mu \mathrm{L}$ metanol kemudian dibagi ke dalam empat tabung reaksi. Tabung pertama digunakan sebagai tabung kontrol, tabung kedua, ketiga, dan keempat berturut-turut ditambahkan $\mathrm{NaOH}, \mathrm{H}_{2} \mathrm{SO}_{4}$ pekat, dan serbuk $\mathrm{Mg}-\mathrm{HCl}$ pekat. Warna pada masing-masing tabung dibandingkan dengan tabung kontrol, jika terjadi perubahan warna maka positif mengandung flavonoid. 


\section{Uji Kuinon}

Sebanyak $1 \times 10^{5} \mu \mathrm{g}$ ekstrak ditambah $5 \times 10^{3} \mu \mathrm{L} \mathrm{KOH} \mathrm{0,5} \mathrm{M} \mathrm{dan} 1 \times 10^{3} \mu \mathrm{L}$ hidrogen peroksida 5\% dipanaskan selama 10 menit, kemudian disaring, diasamkan dengan asam asetat, dan diekstraksi dengan $5 \times 10^{3} \mu \mathrm{L}$ benzena. Lapisan benzena dipisahkan dan ditambahkan ammonia. Hasil positif ditunjukkan jika pada lapisan ammonia terbentuk warna merah dan lapisan benzena tidak berwarna.

\section{Uji Steroid}

Sebanyak $1 \times 10^{5} \mu \mathrm{g}$ ekstrak metanol ditambahkan $2 \times 10^{3} \mu \mathrm{L}$ kloroform kemudian ditambahkan lagi 5 tetes $\mathrm{H}_{2} \mathrm{SO}_{4} 6 \mathrm{M}$. Uji positif adanya steroid pada larutan dengan perubahan warna larutan menjadi coklat.

\section{Uji Triterpenoid}

Untuk uji terpenoid, ekstrak kental metanol yang diperoleh pada tahap ekstraksi ditimbang sebanyak $1 \times 10^{6} \mu \mathrm{g}$ kemudian ditambahkan $20 \times 10^{3} \mu \mathrm{L}$ etanol, $2 \times 10^{3} \mu \mathrm{L}$ kloroform dan $3 \times$ $10^{3} \mu \mathrm{L} \mathrm{H}_{2} \mathrm{SO}_{4}$ pekat. Uji positif adanya terpenoid ditandai dengan perubahan warna larutan menjadi merah.

\section{Uji Identifikasi Senyawa}

Uji identifikasi dilakukan dengan menggunakan FTIR. Instrumen ini digunakan untuk memprediksi senyawa organik aktif dengan mengidentifikasi gugus fungsi melalui serapan sinar inframerah. Ekstrak metanol sebanyak $1 \times 10^{5} \mu \mathrm{g}$ dikeringkan di atas penangas air hingga mengering. Sebanyak $1 \times 10^{3} \mu \mathrm{g}$ ekstrak yang telah dikeringkan dibuat lempeng dengan menambahkan $\mathrm{KBr}$ sebanyak $1 \times 10^{5} \mu \mathrm{g}$. Lempeng tersebut dibaca dengan spektrofotometer inframerah.

\section{HASIL DAN PEMBAHASAN}

\section{Hasil Uji Fitokimia}

Bunga turi merah diekstrak dengan metanol karena pelarut ini sangat baik dalam melarutkan senyawa metabolit sekunder dari sumbernya. Hasil uji fitokimia disajikan pada Tabel 1 dan

\section{Gambar 2.}


Tabel 1. Hasil uji fitokimia ekstrak metanol bunga turi merah (Sesbania grandiflora L. Pers)

\begin{tabular}{lllc}
\hline No & Jenis Uji Fitokimia & \multicolumn{1}{c}{ Hasil Pengamatan } & Hasil Pengujian \\
\hline $\mathbf{1}$ & Alkaloid & & \\
\cline { 2 - 4 } & a. Dragendorff & Endapan coklat jingga & + \\
\cline { 2 - 4 } & b. Wagner & Endapan coklat & + \\
\hline $\mathbf{2}$ & Saponin & Tidak ada gelembung & - \\
\hline $\mathbf{3}$ & Tanin & Larutan putih keruh & + \\
\hline $\mathbf{4}$ & Polifenol & Larutan biru kehitaman & + \\
\hline $\mathbf{5}$ & Flavonoid & Larutan merah ungu & + \\
\hline $\mathbf{6}$ & Kuinon & Larutan merah & + \\
\hline $\mathbf{7}$ & Steroid & Larutan merah & - \\
\hline $\mathbf{8}$ & Triterpenoid & Larutan merah & + \\
\hline
\end{tabular}

Pereaksi Dragendorff merupakan hasil dari campuran bismut nitrat bereaksi dengan kalium iodida membentuk endapan hitam bismut(III) iodida yang kemudian melarut dalam kalium iodida berlebih membentuk kalium tetraiodobismutat. Uji alkaloid dengan pereaksi Dragendorff yang positif ditunjukkan oleh adanya endapan coklat. Pereaksi Wagner terdiri dari kalium iodida (KI) dan iodin $\left(\mathrm{I}_{2}\right)$ dimana keduanya dapat bereaksi dan menghasilkan $\mathrm{I}_{3}{ }^{-}$yang berwarna cokelat. Endapan tersebut merupakan senyawa kompleks kalium-alkaloid yang merupakan hasil dari ion $\mathrm{K}^{+}$akan yang berikatan kovalen koordinat dengan nitrogen pada alkaloid (Marliana et al, 2005).

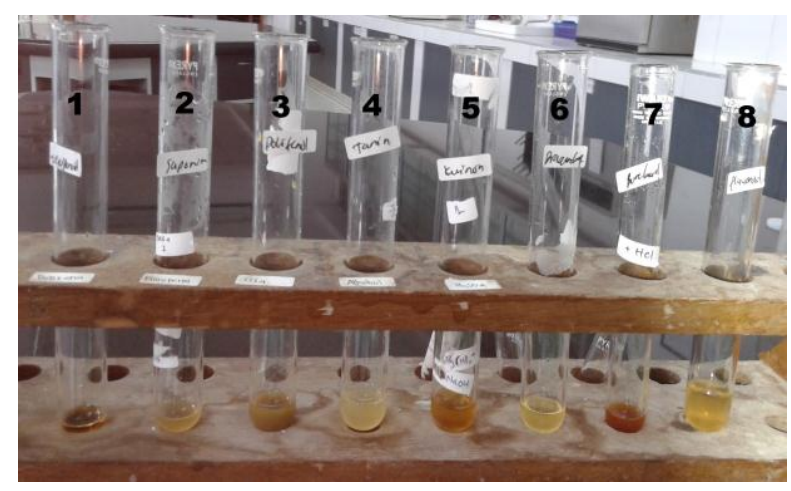

Gambar 2. Foto hasil uji fitokimia terhadap ekstrak metanol bunga turi merah (Keterangan gambar uji: 1. Triterpenoid; 2. Saponin; 3. Polifenol; 4. Tanin; 5. Kuinon; 6. Steroid; 7. Alkaloid; dan 8. Flavanoid)

Hasil positif pada uji tanin ditunjukkan oleh adanya endapan putih pada simplisia setelah ditambah gelatin. Gelatin terdiri dari asam amino yaitu dengan kandungan glisin (27\%), prolin 
(16\%) dan hidroksiprolin (14\%) dan sebagai penstabil dan pengental pada media yang berbasiskan air. Terbentuknya endapan putih disebabkan oleh adanya ikatan hidrogen antara gugus hidroksi tanin dengan gugus karbonil protein pada gelatin (Marliana et al, 2005).

Uji kandungan polifenol menggunakan metode Folin-Ciocalteu yang memanfaatkan reaksi oksidasi dan reduksi kolorimetrik pada sampel yang diduga mengandung senyawa fenolik. Pereaksi Folin-Ciocalteu merupakan larutan kompleks ion polimerik yang dibentuk dari asam fosfomolibdat dan asam heteropolifosfotungstat. Pereaksi ini terbuat dari air, natrium tungstat, natrium molibdat, asam fosfat, asam klorida, litium sulfat, dan bromin (Nurhayati et al, 2012). Pereaksi ini mengoksidasi fenolat (garam alkali) dan mereduksi asam heteropoli menjadi suatu kompleks molibdenum-tungsten (Mo-W). Warna biru yang terbentuk menunjukkan adanya kompleks fosfotungstat-fosfomolibdat hasil reaksi antara gugus fenolik-hidroksil dengan pereaksi Folin-Ciocalteu tersebut.

Flavonoid adalah senyawa yang mempunyai inti $\alpha$-benzopyron. Oksigen pada gugus karbonilnya akan terprotonisasi ketika direaksikan dengan $\mathrm{HCl}$. Hasil reaksinya adalah garam flavilium yang berwarna merah tua (Marlindaa, 2010). Hasil uji ekstrak ini menunjukkan warna merah ungu yang berarti terbentuknya garam flavinium.

Uji kandungan kuinon dilakukan dengan mereduksi oksigen karbonil dengan basa dan peroksida agar terbentuk fenol. Penambahan amonia berfungsi untuk mendeprotonasi gugus fenol pada kuinon sehingga terbentuk ion enolat yang terkonjugasi dengan ikatan pi karbonkarbon cincin benzena. Ion enolat tersebut dapat menyebabkan peristiwa resonansi antarelektron pada ikatan rangkap dua yang ditandai dengan penyerapan cahaya tertentu dan memantulkan warna merah (Harborne, 1984).

Hasil positif pada pengujian triterpenoid ditandai dengan perubahan warna menjadi merah, ungu atau coklat. Munculnya warna ini terjadi karena reaksi oksidasi senyawa terpenoid yang menghasilkan gugus kromofor (karbon tak jenuh terkonjugasi). Senyawa terpenoid akan mengalami asetilasi gugus hidroksil oleh asam asetat anhidrous dilanjutkan dengan eliminasi gugus asetil dan hidrogen sehingga terbentuk ikatan rangkap terkonjugasi. Reaksi lanjutnya berupa penggabungan cincin segienam tak jenuhnya sehingga memperpanjang ikatan rangkap terkonjugasi yang mengabsorpsi spektrum dengan panjang gelombang tertentu (Siadi, 2012).

\section{Hasil Uji Penegasan Senyawa}

Sampel yang telah diuji kandungan senyawa metabolit sekunder melalui pengujian menggunakan beberapa reagen yang khas untuk tiap ujinya perlu ditegaskan keberadaan senyawa dugaan tersebut menggunakan teknik spektroskopi. Salah satu jenis teknik spektroskopi yang digunakan untuk menentukan senyawa organik adalah spektroskopi inframerah.

Sampel yang diuji dengan instrumen FTIR menunjukkan puncak di bilangan gelombang $3262,619 \mathrm{~cm}^{-1}$ dan $3254,931 \mathrm{~cm}^{-1}$ dengan tipe melandai yang menunjukkan adanya regangan gugus fungsi $-\mathrm{OH}$ yang saling berikatan hidrogen dengan gugus fungsi molekul tetangga (Stuart, 2007). Puncak tersebut memiliki intensitas yang relatif tinggi menunjukkan adanya momen dipol 
yang relatif signifikan untuk membentuk medan listrik yang membantu memperkuat penyerapan energi dari sinar IR (Klein, 2012). Puncak berikutnya adalah 2931,949 $\mathrm{cm}^{-1}$ yang menunjukkan adanya regangan ikatan $\mathrm{C}-\mathrm{H}$ dengan tipe hibridisasi $s p^{3}$ untuk atom $\mathrm{C}$-nya.

Puncak selanjutnya di bilangan $1624,899 \mathrm{~cm}^{-1}$ yang menunjukkan adanya vibrasi skeletal atom $\mathrm{C}$ berikatan rangkap dua yang kemungkinan besar milik gugus aromatis. Puncak spektra untuk gugus olefin $(\mathrm{C}=\mathrm{C})$ alifatik ada di bilangan gelombang rata-rata sekitar $1660 \mathrm{~cm}^{-1}$ sedangkan regangan gugus olefin pada aromatis ditunjukkan oleh spektra dengan bilangan gelombang lebih rendah, sekitar $1600 \mathrm{~cm}^{-1}$. Karakteristik ketidakjenuhan $\mathrm{C}=\mathrm{C}$ aromatis sebesar 1,5 kali $\mathrm{C}=\mathrm{C}$ alifatik karena pengaruh konjugasi tiga buah ikatan rangkap dua dalam enam atom karbon siklik. Hal ini mengakibatkan kekuatan ikatan rangkapnya lebih lemah daripada rangkap dalam alifatik sehingga frekuensi regangannya juga lebih rendah (Wade, 2013).

Keberadaan senyawa fenolik semakin dipertegas oleh spektra di daerah sidik jari. Puncak pada bilangan gelombang 1406,265 $\mathrm{cm}^{-1}$ juga merupakan representasi regangan $\mathrm{C}=\mathrm{C}$ cincin aromatis yang mengalami resonansi sehingga menghasilkan serapan dengan bilangan gelombang yang lebih rendah dari rentang $1650-1430 \mathrm{~cm}^{-1}$ (Stuart, 2007 dan Klein, 2012). Karakteristik khas keberadaan ikatan $\mathrm{C}-\mathrm{O}$ senyawa fenolik ditunjukkan oleh puncak dengan intensitas yang kuat pada bilangan gelombang 1046,955 $\mathrm{cm}^{-1}$ yang menandakan regangan ikatan antara C-O (Trifunschi et al., 2015 dan Stuart, 2007). Tampilan hasil uji dengan FTIR ini disajikan pada Gambar 3.

Agilent Resolutions Pro

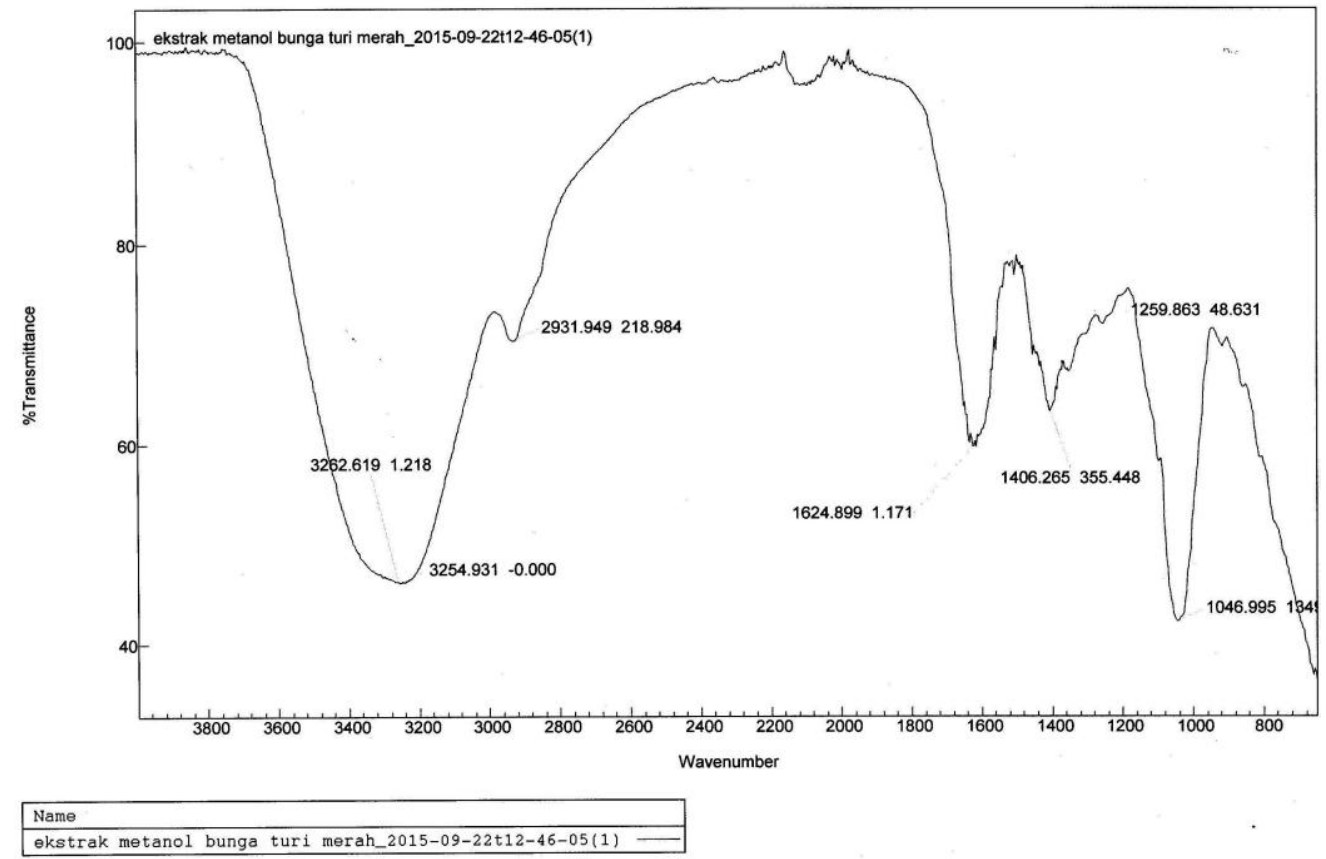

Gambar 3. Spektra hasil uji FTIR terhadap ekstrak metanol bunga turi merah (Sesbania grandiflora L. Pers) 
Spektra tersebut tidak menampilkan adanya ikatan $\mathrm{C}-\mathrm{H}$ dengan tipe hibridisasi $s p^{2}$ yang merupakan pasangan serapan regangan gugus vinil $(\mathrm{C}=\mathrm{CH})$ karena diduga disebabkan oleh jenis sampel yang merupakan crude extract (ekstrak kasar). Sampel yang diuji tanpa melalui proses fraksinasi dan purifikasi sehingga bisa dipastikan di dalamnya terkandung senyawa-senyawa lain yang mengakibatkan kadar senyawa target relatif rendah sehingga absortivitasnya rendah. Hal ini mengakibatkan absorbsi beberapa gugus atom terhadap inframerah sangat rendah sehingga puncaknya tidak muncul dan terjadi peaks overlapping dalam spektra tersebut dari senyawasenyawa yang ada dalam sampel (Stuart, 2007). Kecenderungan ini juga terlihat dari beberapa hasil penelitian spektroskopi IR tentang senyawa fenolik menggunakan crude extract (CruzEspinoza et al., Deepa et al., 2014, dan Trifunschi et al., 2015).

Pola lokasi bilangan gelombang, bentuk, dan intensitas spektra di penelitian ini juga mirip dengan hasil beberapa penelitian tentang elusidasi senyawa fenolik dari crude extract tumbuhan yang berbeda. Sebaran spektra tersebut dapat dilihat di Tabel 2. Penelitian Cruz-Espinoza et al. tentang ekstrak aseton daun Moringa oleifera melaporkan keberadaan senyawa fenolik melalui uji FTIR yang dikuatkan dengan analisis kuantitatif kandungan fenolik total dengan analisis multivariat. Deepa et al. (2014) melakukan skrining fitokimia terhadap ekstrak kasar Salicornia brachiate yang dilanjutkan dengan analisis FTIR dan melaporkan adanya senyawa fenolik. Keberadaan cincin aromatis senyawa tersebut ditegaskan melalui uji spektrofotometri UV-Vis. Trifunschi et al. (2015) melakukan investigasi keberadaan senyawa fenolik dalam ekstrak etanol (50\%) tanaman Viscum album and Allium sativum dengan bantuan FTIR. Hasilnya melaporkan adanya senyawa falvanoid dan polifenol yang ditegaskan dengan uji kuantitatif kandungan total kedua gugus senyawa tersebut menggunakan metode dalam Romanian Pharmacopoeia.

Tabel 2. Hasil uji spektroskopi IR dari beberapa penelitian tentang karakterisasi spektroskopi ekstrak kasar dari tumbuhan yang berbeda-beda

\begin{tabular}{|c|c|c|c|c|}
\hline Peneliti & $\begin{array}{l}\text { Spektra gugus } \\
-\mathrm{OH} \text { fenolik }\end{array}$ & $\begin{array}{c}\text { Spektra } \\
\text { gugus -CH } \\
\left(s p^{3}\right)\end{array}$ & $\begin{array}{c}\text { Spektra } \mathrm{C}=\mathrm{C} \\
\text { aromatis }\end{array}$ & $\begin{array}{c}\text { Spektra } \\
\text { C-OO }\end{array}$ \\
\hline $\begin{array}{l}\text { Cruz-Espinoza } e t \\
\text { al. }\end{array}$ & $\begin{array}{l}3285 \mathrm{~cm}^{-1} \\
\text { (melandai) }\end{array}$ & $2920 \mathrm{~cm}^{-1}$ & $\begin{array}{l}1615 \text { dan } 1500 \\
\mathrm{~cm}^{-1}\end{array}$ & - \\
\hline Deepa et al., 2014 & $\begin{array}{l}3448,4 \mathrm{~cm}^{-1} \\
\text { (melandai) }\end{array}$ & $2914,28 \mathrm{~cm}^{-1}$ & $\begin{array}{l}1637,4 \mathrm{~cm}^{-1} \\
\text { dan } 1404 \mathrm{~cm}^{-1}\end{array}$ & $\begin{array}{l}1319,59 \\
\mathrm{~cm}^{-1}\end{array}$ \\
\hline $\begin{array}{l}\text { Trifunschi et al., } \\
2015 \text { (Viscum } \\
\text { album) }\end{array}$ & $\begin{array}{l}3360,78 \mathrm{~cm}^{-1} \\
\text { (melandai) }\end{array}$ & $2979,21 \mathrm{~cm}^{-1}$ & $1644,77 \mathrm{~cm}^{-1}$ & $\begin{array}{l}1044,24 \\
\mathrm{~cm}^{-1}\end{array}$ \\
\hline $\begin{array}{l}\text { Trifunschi et al., } \\
2015 \text { (Allium } \\
\text { sativum) }\end{array}$ & $\begin{array}{l}3339,10 \mathrm{~cm}^{-1} \\
\text { (melandai) }\end{array}$ & $2979,07 \mathrm{~cm}^{-1}$ & $1644,99 \mathrm{~cm}^{-1}$ & $\begin{array}{l}1086,78 \\
\mathrm{~cm}^{-1}\end{array}$ \\
\hline
\end{tabular}


Berdasarkan analisis menggunakan spektroskopi IR pada ekstrak metanol bunga turi merah ini, gugus fungsi yang terbaca adalah hidroksida, olefin, dan aromatis. Fakta ini yang didukung oleh beberapa referensi analisis senyawa fenolik menegaskan bahwa ekstrak metanol bunga turi merah mengandung senyawa fenolik. Gugus tersebut merupakan komponen utama dari senyawa fenolik. Hampir semua senyawa metabolit sekunder memiliki gugus fungsi hidroksida di dalam srukturnya. Gugus fungsi ini dikenal sebagai komponen kimia yang bertanggungjawab terhadap aktivitas biologisnya bagi makhluk hidup. Kemampuannya membentuk ikatan hidrogen merupakan salah satu faktor yang membantu senyawa aktifnya mudah larut dalam pelarut air serta berinteraksi dengan protein target di dalam sistem organisme. Senyawa fenolik ekstrak kasar dari semua jenis bunga dilaporkan memiliki aktivitas antimikrobial tertinggi dibandingkan bagian tanaman lainnya (Munde-Wagh et al, 2012).

Beberapa penelitian secara khusus menguji kandungan senyawa polifenol dan flavonoid dalam bunga turi dan potensi bioaktivitasnya. Kalpana et al. (2012) telah melakukan ekstraksi bunga turi (Sesbania grandiflora) dengan aseton (70\%) dan melaporkan kandungan polifenol

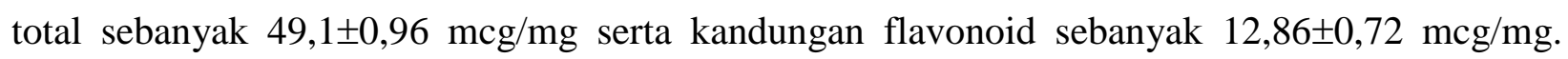
Penelitian ini juga melaporkan bahwa ekstraknya memiliki potensi antimikrobial yang tinggi terhadap bakteri-bakteri penyebab infeksi. Kumar et al. (2015) melaporkan bahwa senyawa golongan flavonoid dalam ekstrak alkohol $70 \%$ bunga S.grandiflora diduga menurunkan kadar gula darah mencit diabetes yang diinduksi dengan Alloxan. Ekstrak ini mampu melindungi sel islet Langerhans dalam pankreas hewan tersebut.

Mandey et al. (2003) menyebutkan bahwa para peneliti telah mengisolasi senyawa flavonol glikosida dari bunga turi seperti Kalyanagurunathan et al (1985) yang mengisolasi kaempferol-3rutinosida sedangkan Andal dan Sulochana (1986) telah mengisolasi kaempferol-7-glukosida dan kaempferol-3,7-diglukosida. Senyawa-senyawa tersebut diduga mengaktifkan proses produksi TNF- $\alpha$ (tumour necrosis factor) yang berhubungan dalam penyakit kardiovaskular and inflamasi kronis (Mandey et al, 2003). Dari beberapa penelitian tersebut, ekstrak metanol bunga turi merah berpotensi mengandung senyawa dominan dari golongan fenolik dan flavonoid yang memiliki bioaktivitas terhadap sistem oganisme.

\section{PENUTUP}

Ekstrak metanol bunga turi merah (Sesbania grandiflora L. Pers) mengandung beberapa senyawa metabolit sekunder (alkaloid, tanin, polifenol, flavonoid, kuinon, dan triterpenoid) yang dibuktikan dengan uji fitokimia. Uji spektroskopi FTIR menunjukkan bahwa senyawa aktif dalam ekstrak tersebut mengandung gugus fungsi hidroksida $(-\mathrm{OH})$, olefin $(\mathrm{C}=\mathrm{C})$, dan aromatis yang merupakan penyusun senyawa fenolik. Hasil penelitian ini merupakan informasi awal yang akan digunakan untuk isolasi dan separasi senyawa murni serta uji aktivitasnya yang membantu menyelesaikan masalah metabolisme dalam tubuh manusia. 


\section{DAFTAR PUSTAKA}

Avalaskar A.N., Itankar .P.R., Joshi V.S., Agrawal.M., dan Vyas J., 2011, Phytochemical and TLC studies of ethanolic extract of Sesbania grandiflora (Fabaceae). Int.J. Pharm.Tech. Res., 3 (3), 1346-1349.

Cruz-Espinoza, J.E., Orduña-Díaz, Rosales-Perez,M., Zaca-Morán, A. M. O., Delgado-Macuil, R., Gayou, V.L., dan Rojas-López, M., FTIR analysis of phenolic extracts from Moringa oleifera leaves. (online). www.smbb.com.mx/SMBB/III-C36. Diakses pada 21 Mei 2017.

Deepa, S., Sripriya N. S., dan Bangaru C., 2014, Studies on the phytochemistry, spectroscopic characterization and antibacterial efficacy of Salicornia brachiata, Int J Pharm Pharm Sci, 6 (6): 430-432.

Hasan, N., Osman, H., Mohamad, S., Chong, W.K., Awang, K., dan Zahariluddin, A.S.M., 2012, The chemical components of Sesbania grandiflora root and their antituberculosis activity, Pharmaceuticals, 5: 882-889.

Hasan, N., Osman, H., Chong, W.K., Awang, K., dan Manshoor, N., 2012, Isolation and characterisation of 1,1'-binaphthalene-2,2'-diol: a new biaryl natural product from Sesbania grandiflora root, Journal of Basic \& Applied Sciences, 8: 253-256.

Harborne, J. B., 1984, Phytochemical methods: a guide to modern techniques of plant analysis, New York: Chapman and Hall.

Hussain, A. Z. dan Kumaresan, S., 2014, GC-MS studies and phytochemical screening of Sesbania grandiflora L., J. Chem. Pharm. Res., 6 (9): 43-47.

Jiraungkoorskul, K., dan Jiraungkoorskul, W., 2013, Sesbania grandiflora: new nutraceutical use as antidiabetic, Int. J. Pharm. Pharm. Sci., 7(7): 26-29.

Klein, D. R., 2012, Organic chemistry, New Jersey: John Wiley \& Sons.

Kumar, R., Janadri, S., Kumar, S., Dhanajaya, D.R., dan Swamy, S., 2015, Evaluation of antidiabetic activity of alcoholice of Sesbania grandiflora flower in alloxan induced diabetic rats, Asian Journal of Pharmacy and Pharmacology, 1(1): 21-26.

Mandey, F.K, Usman, H., Mursalim, M., dan Pagama, N., 2003, Study towards secondary metabolites of "Turi" (Sesbania Grandiflora, L): primarily qualitative study of a steroid in the root of turi, Marina Chimica Acta, 1(1): 9-11.

Marliana, S.D., Suryanti, V., Suyono, 2005, Skrining fitokimia dan analisis kromatografi lapis tipis komponen kimia buah labu siam (Sechium edule Jacq. Swartz.) dalam ekstrak etanol, Biofarmasi, 3 (1): 26-31. 
Marlindaa, M., Meiske S. Sangia, Audy D. Wuntua, 2010, Analisis senyawa metabolit sekunder dan uji toksisitas ekstrak etanol biji buah alpukat (Persea americana Mill.), Jurnal MIPA Unsrat Online 1(1): 24-28.

Munde-Wagh, K. B., Wagh, V.D., Toshniwal, S.S., dan Sonawane, B.R., 2012, Phytochemical, antimicrobial evaluation and determination of total phenolic and flavonoid contents of Sesbania grandiflora flower extract, Int. J. Pharm. Sci., 4 (4): 229-232.

Nurhayati, Kusoro Siadi dan Harjono, 2012, Pengaruh konsentrasi natrium benzoat dan lama penyimpanan pada kadar fenolat total pasta tomat, Indo. J. Chem. Sci., 1(2): 158-163.

Padmalochana, K. dan Rajan M.S.D, 2014, Antimicrobial activity of aqueous, ethanol and Acetone extracts of Sesbania grandiflora leaves and its phytochemical characterization, International Journal of Pharma Sciences and Research (IJPSR), 5(12): 957-962.

Powthong, P., Jantrapanukorn, B., Thongmee, A., Suntornthiticharoen, P., 2012,Evaluation of endophytic fungi extract for their antimicrobial activity from Sesbania grandiflora (L.) Pers., Int. J. Pharm. Biomed. Res., 3(2): 132-136.

Reji, A.F. dan Alphonse, R.N., 2013, Phytochemical study on Sesbania grandiflora, J. Chem. Pharm. Res., 5(2): 196-201.

Siadi, K, 2012, Ekstrak bungkil biji Jarak Pagar (Jatropha curcas) sebagai biopestisida yang efektif dengan penambahan larutan NaCl, Jurnal MIPA 35(1): 80-81.

Stuart, B, 2007, Infrared spectroscopy: fundamentals and applications, New Jersey: John Willey \& Sons.

Trifunschi, S., Munteanu, M.F., Agotici, V., Pintea (Ardelean), S., dan Ramona Gligor2, 2015, Determination of flavonoid and polyphenol compounds in Viscum album and Allium sativum extracts, International Current Pharmaceutical Journal, 4(5): 382-385.

Wade, L. G., 2013, Organic chemistry, Glenview: Pearson Education. 